Jurnal Inkofar * Volume 1 No. 2, Desember 2017 * ISSN: 2615-3645 (Print) / 2581-2920 (Online)

Tersedia secara online di: http://www.politeknikmeta.ac.id/meta/ojs/

\title{
JURNAL REVIEW: ANALISIS BAHAN-BAHAN ALTERNATIF PENGOLAHAN DALAM PEMBUATAN KERTAS
}

\author{
Lilis Rosmainar \\ Program Studi Farmasi, Politeknik META Industri Cikarang \\ Email: 1ilisr@politeknikmeta.ac.id
}

\begin{abstract}
Paper has become a major need for human or company in the field of archiving and delivery of information and making of cleaning tool. Increased demand for paper is part of an increase in forest and tree exploitation, since the main ingredient in paper making is wood. Thus looking for alternative materials in papermaking done and in carefully by various parties. Some researchers have found that many types of plants can be used as alternative materials in paper making, such as sugar cane, paper waste, banana stalk, water hyacinth, corncobs, straw, empty palm bunches, peanut shells, elephant grass, aren, and leaves kirinyuh. The method used from several studies that have been done that is by using mechanic and chemical pulping method by using $\mathrm{NaOH}$ and $\mathrm{NaClO}$. Based on the results obtained most of the types of plants used as an alternative material of paper making is from the family plant species Poaceae with the resulting paper is art paper, while that can be used for writing paper is using empty bunches of oil palm. Therefore, based on the results obtained by the type of plant used in some research found that the type of plant that has been used both to produce art paper.
\end{abstract}

Keywords:Paper, Plants, Poaceae

\begin{abstract}
ABSTRAK
Kertas telah menjadi kebutuhan utama bagi manusia atau perusahaan dalam bidang pengarsipan dan penyampaian informasi serta pembuatan alat pembersih. Peningkatan permintaan kertas menjadi bagian dari peningkatan eksploitasi hutan dan pohon, karena bahan utama dalam pembuatan kertas adalah kayu. Dengan demikian mencari bahan-bahan alternatif dalam pembuatan kertas dilakukan dan di teliti oleh berbagai pihak. Beberapa peneliti menemukan bahwa banyak jenis tanaman yang bisa digunakan sebagai bahan alternatif dalam pembuatan kertas, yaitu seperti tebu, sampah kertas, batang pisang, enceng gondok, kulit jagung, tongkol jagung, jerami, tandan kosong kelapa sawit, kulit kacang, rumput gajah, serat aren, dan daun kirinyuh. Metode yang digunakan dari beberapa penelitian yang telah dilakukan yaitu dengan menggunakan cara kimia (chemical pulping) dengan menggunakan $\mathrm{NaO}$. Berdasarkan hasil yang diperoleh sebagian besar jenis tanaman yang digunakan sebagai bahan alternatif pembuatan kertas adalah dari jenis tanaman famili Poaceae dengan kertas yang dihasilkan adalah kertas seni (art paper), sedangkan yang dapat digunakan untuk kertas tulis adalah menggunakan tandan kosong kelapa sawit. Oleh karena itu berdasarkan hasil yang diperoleh jenis tanaman yang digunakan pada beberapa penelitian didapatkan bahwa jenis tanaman yang telah digunakan baik untuk menghasilkan kertas seni (art paper).
\end{abstract}

Kata Kunci: Kertas, kayu, Poaceae

\section{PENDAHULUAN}

Kebutuhan kertas di Indonesia meningkat, bahkan permintaan kertas dunia juga mengalami peningkatan, tentu dengan naiknnya permintaan kertas dalam negeri dan luar negeri membuat bahan baku pembuatan kertas meningkat. Bahan pembuatan kertas masih didominasi oleh kayu atau pohon hampir $90 \%$ bahan utama pembuatan kertas adalah Kayu. Tingginya permintaan kertas kemungkinan terjadinya eksploitasi hutan akan meningkat.

Hasil survei yang dilakukan Spire Research terhadap 100 perusahaan Indonesia di bulan Maret 2015 menunjukkan bahwa $40 \%$ dari perusahaan yang disurvei memberikan indikasi atas peningkatan konsumsi kertas dalam dua tahun terakhir. Hanya 20\% yang menyebutkan penurunan konsumsi kertas di kantor, sedangkan $40 \%$ lainnya menyebutkan tidak terjadi perubahan konsumsi kertas yang signifikan. 
Mayoritas $(53,3 \%)$ perusahaan di sektor finansial, asuransi, real estate adalah perusahaan di mana konsumsi kertas meningkat dalam dua tahun terakhir. Tren serupa juga terlihat dari sektor ini di negara Asia Pasifik lainnya. Hasil survey menunjukkan bahwa 51,5\% perusahaan dari sektor penyedia layanan jasa lainnya seperti logistik, distribusi, kesehatan, software, advertising dan media serta $38,5 \%$ dari total di sektor perdagangan dan ritel juga memberikan tren yang sama.

Divisi marketing terlihat sebagai pengguna terbesar, seperti yang diindikasikan (24\%). Divisi finance adalah departemen berikutnya dengan penggunaan terbesar (11\%), diikuti oleh divisi administrasi (9\%).Dari beragam keperluan penggunaan kertas, mencetak laporan adalah pemakaian yang terbesar (36\%) dan juga fotokopi, pembuatan proposal, mencetak sketsa, dan menyiapkan dokumen tender (masing-masing 5\%).

Badan Penelitian dan Pengembangan Industri (BPPI) merilis data pada, tahun 2013 Indonesia memiliki 82 industri pulp dan kertas yang terdiri atas 4 industri pulp, 73 industri kertas, serta 5 industri pulp kertas terintegrasi dengan kapasitas terpasang industri pulp dan kertas sebesar 18,96 juta ton.

Realisasi produksi pulp dan kertas masing-masing 4,55 juta ton dan 7,98 juta ton kertas. Dengan kemampuan produksi tersebut Indonesia menempati peringkat ke-9 untuk produsen pulp terbesar di dunia dan ke-6 untuk produsen kertas terbesar di dunia.Dari sisi ekspor, Indonesia mampu mengekspor pulp sebesar 3,75 juta ton dengan nilai 1,85 miliar dolar AS dan mengekspor kertas sebesar 4,26 juta ton dengan nilai 3,76 miliar dolar AS. Adapun negara tujuan ekspor terbesar adalah Uni Eropa, Amerika Serikat, dan Tiongkok.

Saat ini konsumsi kertas di dunia se-banyak 394 juta ton dan diperkirakan akan meningkat menjadi 490 juta ton pada 2020. Sementara di dalam negeri konsumsi kertas per kapita masih sangat jauh dari rata-rata konsumsi negara lainnya sehingga masih sangat potensial untuk berkembang.

Penggunaan media online, pada kenyataannya tidak akan menghambat perkembangan industri pulp dan kertas karena penduduk dunia diproyeksikan menjadi 9 miliar orang pada tahun 2050 dan hampir 60\%-70\% berada di Asia yang diprediksi masih menggunakan kertas untuk berbagai keperluan.

Melihat peningkatan permintaan kertas semakin meningkat, maka perlu dilakukan atau dicari bahan baku alterntif dalam pembuatan kertas supaya dominasi kayu dalam pembuatan kertas bisa di kurangi. Penelitian ini dilakukan untuk mencari bahan-bahan alternatif pengolahan dalam pembuatan kertas.

\section{BAHAN DAN METODE PENELITIAN}

Penelitian yang telah dilakukan menggunakan bahan alternatif pembuat kertas seperti tebu, sampah kertas, batang pisang, enceng gondok, kulit jagung, tongkol jagung, jerami, tandan kosong kelapa sawit, kulit kacang, rumput gajah, serat aren, dan daun kirinyuh.

Metode yang telah dilakukan berupa metode secara mekanik atau penghancuran bahan sehingga menjadi pulp dan secara kimia (chemical pulping) dengan menggunakan $\mathrm{NaOH}$.

\section{HASIL ANALISIS DATA DAN PEMBAHASAN BAHAN ALTERNATIF PEMBUATAN KERTAS}

\subsection{Tebu dan Sampah Kertas}

Kertas yang dihasilkan dari campuran ampas tebu dan sampah kertas ini memiliki tekstur yang kasar, keras, rapuh, memiliki ikatan partikel yang padu, dan penampakan serat yang timbul dipermukaan kertas sehingga lebih baik digunakan sebagai kertas seni. Berikut adalah hasil perlakuan dengan rancangan acak lengkap faktorial dari ampas tebu $(100 \%, 50 \%$, dan $0 \%)$.

\begin{tabular}{|c|c|c|c|}
\hline $\begin{array}{c}\text { Perlakuan } \\
\text { (Ampas Tebu : } \\
\text { Ampas Kertas) }\end{array}$ & Gramatur $\left(\mathbf{g} / \mathbf{m}^{\mathbf{2}}\right)$ & $\begin{array}{c}\text { Kekuatan Tarik } \\
\text { (MPa) }\end{array}$ & $\begin{array}{c}\text { Ketahanan Sobek } \\
\text { (N/mm) }\end{array}$ \\
\hline $100 \%: 0 \%$ & 0,0289 & 0,0264 & 0,0266 \\
\hline $50 \%: 50 \%$ & 0,1215 & 0,0513 & 2,7888 \\
\hline $0 \%: 1000 \%$ & 0,1456 & 0,1641 & 4,6888 \\
\hline
\end{tabular}

Hasil terbaik diperoleh pada konsentrasi kertas $100 \%$ dengan gramatur sebesar $0,1456 \mathrm{~g} / \mathrm{m}^{2}$, kekuatan tarik 0,1641 MPa, dan ketahanan sobek 4,6888 N/mm (Vitaloka, 2017). 
Jurnal Inkofar * Volume 1 No. 2, Desember 2017 * ISSN: 2615-3645 (Print) / 2581-2920 (Online)

Tersedia secara online di: http://www.politeknikmeta.ac.id/meta/ojs/

\subsection{Batang Pisang}

Penelitian ini dilakukan pada batang pisang yaitu dengan menguji perolehan pulp dari batang pisang melalui proses soda. Bahan baku pulp terdiri atas selulosa, hemiselulosa, lignin dan ekstraktif. Pulp dapat dibuat dengan cara kimia, yaitu memasak bahan baku dengan menggunakan bahan kimia yang sesuai di dalam Reaktor. Batang pisang yang berukuran $1 \mathrm{~cm}$ sebanyak 10 gram dimasak dengan menvariasikan konsentrasi $\mathrm{NaOH}$ dan waktu pemasakan. Konsentrasi $\mathrm{NaOH}$ yang digunakan 0,$5 ; 1 ; 1,5 ; 2$ dan $2,5 \%$ dengan waktu pemasakan $30 ; 60$; 90; 120 dan 150 menit. Kondisi terbaik dari hasil penelitian diperoleh pulp $61.43 \%$, kandungan selulosa $83.3 \%$, dan kandungan lignin $2.97 \%$ pada waktu pemasakan 120 menit dan konsentrasi $\mathrm{NaOH} 2 \%$.

Pembuatan pulp menggunakan proses kimia memiliki beberapa keuntungan seperti dapat dilakukan pada semua jenis bahan baku, kekuatan pulp tinggi, pulp yang dihasilkan dapat digunakan untuk pembuatan rayon, serta kualitas kertas yang dihasilkan lebih tinggi. Pada proses pemasakan, faktor yang berpengaruh antara lain bahan baku, konsentrasi bahan kimia, suhu, waktu pemasakan, konsentrasi pelarut, dan perbandingan cara pemasak terhadap bahan baku. Pada penelitian ini pulp yang diperoleh berkisar antara 35,18\% - 61,43\% bervariasi menurut kondisi operasi. Hasil yang diperoleh ini lebih baik dari pada range perolehan pulp yang dihasilkan industri pulp kimia dalam range 35\% - 63\%. Ini berarti pulp batang pisang dapat digunakan sebagai pulp kertas skala industri kimia karena sudah memenuhi standar kualitas pulp kertas menurut Nugroho dan Rusmanto. (Syamsul, 2015).

\subsection{Eceng Gondok}

Eceng gondok memiliki kandungan selulosa 18-31\%, lignin 7-26\%, hemiselulosa 18- 43\%, dan ash $15-26 \%$ dengan kandungan air $85-95 \%$ (Girisuta, 2007). Kondisi operasi yang baik untuk memperoleh serat selulosa batang eceng gondok dengan metode chemical pulping pada konsentrasi $\mathrm{NaOH} 2,5 \%(\mathrm{w} / \mathrm{v})$ selama 15 menit dengan suhu $120^{\circ} \mathrm{C}$, tekanan 14,5 Psi dan yield sebesar $32,31 \%$. Rapat massa $(\mathrm{g} / \mathrm{cm} 3)$ produk kertas yang baik yaitu pada variasi loading komposisi 2:1 untuk batang eceng gondok dan serat Koran bekas sebesar 0,57 g/cm3. Berdasarkan observasi SEM dan XRD, serat eceng gondok sebelum chemical treatment masih terikat dengan lignin dan setelah treatment serat eceng gondok berukuran $80-100 \mathrm{~nm}$ serta proses chemical pulping meningkatkan karakteristik peak intensity selulosa dari batang eceng gondok sebesar 5,66\% (selulosa I) dan 8,26\% (selulosa II). Pada penelitian ini juga dilakukan percobaan untuk melihat jumlah yield yang dihasilkan pada perbandingan batang Eceng Gondong dengan koran bekas dengan berbagai konsentrasi komposisi, maka dihasilkan jumlah yield yang paling banyak dengan komposisi Eceng Gondong berbanding Koran Bekas (0:1) sebanyak $87,19 \%$. Hal ini juga menunjukkan bahwa penggunaan koran bekas masih memiliki kedudukan yang paling baik dalam menghasilkan jumlah yield yang paling banyak untuk pembuatan kertas (Fatyasari, 2013).

3.4 Kulit Jagung, Tongkol Jagung, dan Daun Jati

Pembuatan kertas dari Kulit jagung dan tongkol Jagung dengan variasi Daun Jati menghasilkan kertas seni dengan hasil uji sebagai berikut:

\begin{tabular}{|l|c|c|}
\hline \multicolumn{1}{|c|}{$\begin{array}{c}\text { Perlakuan (Kulit Jagung:Tongkol Jagung : } \\
\text { Daun Jati) }\end{array}$} & $\begin{array}{c}\text { Kekuatan } \\
\text { Tarik (N) }\end{array}$ & $\begin{array}{c}\text { Kekuatan Sobek } \\
\text { (N) }\end{array}$ \\
\hline 75gr : 25gr : 50gr (Paling Kuat) & 13,7116 & 21,9396 \\
\hline 25gr : 75gr : 50gr (Paling Rendah) & 6,9821 & - \\
\hline 25gr : 75gr : Tanpa Daun Jati (Paling Rendah) & - & 7,6681 \\
\hline
\end{tabular}

Kertas seni yang banyak disukai masyarakat diperoleh untuk perlakuan $75 \mathrm{gr}$ kulit jagung : $25 \mathrm{gr}$ tongkol Jagung : tanpa daun jati dengan hasil warna kuning/cerah, serat tidak nampak, tekstur sangat halus dan perlakuan 75gr kulit jagung : 25gr tongkol Jagung : 50gr daun jati dengan hasil warna coklat tua/tegas, serat nampak, tekstur kasar (Putri, 2015).

Pada penelitian ini, disarankan menggunakan bahan baku kulit jagung yang sudah dalam keadaan kering dan tongkol jagung yang muda maupun tua. Proses pemasakan bahan baku sebaiknya dipisah dan dalam waktu yang berbeda, karena tingkat kekerasan antara tongkol jagung dan kulit jagung berbeda. Proses penggilingan (blender) lebih baik sedikit demi sedikit agar pulp yang dihasilkan lebih halus. Proses pencetakan seharusnya lebih hati-hati agar kertas 
seni yang dihasilkan mempunyai ketebalan yang sama dan rata. Proses penjemuran kertas sebaiknya dalam waktu dan suhu yang sama agar warna yang dihasilkan kertas seni merata/sepadan. Pewarna sebaiknya ditambah dengan pewarna alami yang lain agar kertas seni yang dihasilkan lebih menarik dan bervariasi warnanya.

\subsection{Jerami}

Jerami padi bisa digunakan untuk pembuatan kertas seni dan produk kerajinan karena jerami padi memiliki tekstur dan serat yang unik. Pembuatan kertas seni (art paper) dari Jerami dapat dilakukan dengan komposisi pemasakan yang memiliki rendemen 70,78\%. Hasil organoleptik kertas seni dari jerami padi secara keseluruhan dapat menghasilkan corak yang bergelombang dan homogen, unsur garis lengkung dan diagonal, tekstur yang kasar, halus, sangat kasar dan dengan warna kecoklatan, kream, kuning dan hijau. Kertas seni dari jerami padi bisa membuat unsur kerajinan seperti, kotak tissue, kotak pensil dan bingkai foto

Kertas seni yang dibuat secarah manual menghsilkan kertas seni yang baik, dimana tekstur, warna , dan corak secara visual depengaruhi oleh proses pemasakan, pencucuian, pengilingan/blenderan, pencetakan dan pengeringan selain itu juga tergantung pada ketelitian dari individu pembuatnya. Kertas seni yang dihasilkan berbeda dengan kertas budaya seperti HVS, kwarto, dan lain-lain seperti yang digunakan sehari-hari. Dimana kertas budaya ini mempunyai permukaan yang licin dan rata sementara kertas seni ini selain memiliki permukaan yang kasar juga tidak merata (Lopes, 2013).

\subsection{Tandan Kosong Kelapa Sawit dan Selulosa Mikrobial Nata de Cassava}

Rendemen untuk pulp tandan kosong kelapa sawit (TKKS) dan pulp selulosa mikrobial berada pada kisaran $6062 \%$ (basis kering). Hasil pengujian untuk gramatur target 60 dan $120 \mathrm{~g} / \mathrm{m} 2$ berturut turut untuk gramatur berada pada selang 59,878,9 g/m2 \& 107,6145,3 g/m2, Indeks tarik tertinggi untuk gramatur target $60 \& 120 \mathrm{~g} / \mathrm{m} 2$ diperoleh pada komposisi nata de cassava $100 \%$ dengan nilai $0,048 \mathrm{kNm} / \mathrm{g}$ dan pada komposisi $25: 75$ dengan nilai $0,067 \mathrm{kNm} / \mathrm{g}$. Indeks sobek tertinggi diperoleh pada komposisi 75:25 pada kedua gramatur target dengan nilai berturut-turut 8,22 dan $7,72 \mathrm{mN} \mathrm{m} 2 / \mathrm{g}$.

Ketahanan lipat terbaik diperoleh pada komposisi 50:50 dengan 108,5 lipatan ganda untuk gramatur target $60 \mathrm{~g} / \mathrm{m} 2$ dan pada komposisi 0:100 dengan 397,5 lipatan ganda pada gramatur target $120 \mathrm{~g} / \mathrm{m} 2$. Daya serap air untuk masing-masing gramatur target berturut-turut terletak pada selang 56,9211,3 \& 75398,1 g/m2 pada sisi halus serta mencapai $404,5 \mathrm{~g} / \mathrm{m} 2$ pada gramatur target 120 pada sisi kasar. Derajat putih terbaik pada kedua gramatur target diperoleh pada komposisi nata de cassava 100\% dengan nilai berturut-turut 44,98 dan 32,62\%. Opasitas cetak terbaik pada kedua gramatur target diperoleh pada komposisi 75:25 dengan nilai berturutturut 97,55 dan $99,38 \%$.

Tambahan pulp selulosa mikrobial dapat meningkatkan kekuatan fisik pada kertas dan mengurangi kemampuan daya serap air secara signifikan. Selain itu penambahan aditif dapat meningkatkan gramatur, indeks tarik dan ketahanan lipat serta dapat menurunkan kemampuan daya serap air kertas. Berdasarkan sifat fisik dan mekaniknya, campuran pulp TKKS dan pulp selulosa mikrobial dapat mensusbstitusi pulp kayu dalam pembuatan kertas. Kertas campuran pulp TKKS dan selulosa mikrobial memiliki nilai daya serap air yang rendah sehingga berpotensi menggantikan pulp kayu untuk digunakan sebagai kertas tulis, kertas gambar, kertas kalkir, dan kertas kemasan (Syamsu, 2014).

\subsection{Kulit Kacang dan Bulu Ayam dengan $\mathrm{NaOH}$ dan $\mathrm{CaO}$}

Uji ketahanan tarik kertas dari Limbah Bulu Ayam dan KulitKacang dengan menggunakan $\mathrm{NaOH}$ dan $\mathrm{CaO}$, diketahui bahwa ketahanan tarik paling tinggi pada perlakuan J1A1 (Bahan kimia $\mathrm{NaOH} 15 \%$ dan Bulu ayam 50\%: Kulit Kacang 50\%) dengan rata-rata ketahanan 2.3531N, diikuti dengan J1A2 (2.2732 N), J2A1 ( $2.1591 \mathrm{~N})$, J2A2 (1.0875 N), J1A3 (0.9657 $\mathrm{N})$, J2A3 $(0.7433 \mathrm{~N})$. Ketahanan tarik yang berbeda dikarenakan setiap perlakuan menggunakan limbah bulu ayam dan kulit kacang dengan perbandingan prosentase yang berbeda. Perlakuan yang memiliki nilai kekuatan tarik yang paling tinggi yaitu pada perlakuan J1A1 (prosentase bulu ayam dan kulit kacang tanah 50\%:50\%). (Asngad, 2016)

\subsection{Rumput Gajah ( Pennisetum Purpureum) dengan $\mathrm{NaOH}$ dan $\mathrm{Na2CO3}$}

Berdasarkan hasil penelitian kertas rumput gajah melalui Chemical Pulping (proses Kimia) dengan menggunakan $\mathrm{NaOH}$ dan $\mathrm{Na}_{2} \mathrm{CO}_{3}$, diketahui bahwa ketahanan tarik paling tinggi pada 
Jurnal Inkofar * Volume 1 No. 2, Desember 2017 * ISSN: 2615-3645 (Print) / 2581-2920 (Online)

Tersedia secara online di: http://www.politeknikmeta.ac.id/meta/ojs/

perlakuan $\mathrm{B} 2 \mathrm{~K} 1$ (Bahan kimia $\mathrm{Na}_{2} \mathrm{CO}_{3}$ dan konsentrasi 10\%) dengan rata-rata ketahanan $11,7733 \mathrm{~N}$, diikuti dengan B1 K1 $(9,5169 \mathrm{~N}), \mathrm{B} 2 \mathrm{~K} 2(8,7090 \mathrm{~N}), \mathrm{B} 1 \mathrm{~K} 2(5,9216 \mathrm{~N}), \mathrm{B} 2 \mathrm{~K} 3$ (7, $2126 \mathrm{~N}), \mathrm{B} 1 \mathrm{~K} 3(4,6841 \mathrm{~N})$. Ketahanan tarik yang berbeda dikarenakan setiap perlakuan mempunyai konsentrasi bahan kimia $\left(\mathrm{Na}_{2} \mathrm{CO}_{3}\right.$ dan $\mathrm{NaOH}$ yang berbeda, jika semakin besar konsentrasi bahan kimia yang digunakan maka semakin kuat bereaksi dengan lignin dan akan menyebabkan selulosa terdegradasi dan serat akan rusak, tidak dapat terjalin sempurna. Rusaknya serat akanmempengaruhi ikatan antar serat yang terjadi, karena jika ikatan antar serat kurang maka ketahanan tarik kertas juga lemah. Karena masing-masing perlakuan berbeda konsentrasi bahan kimianya maka ketahanan tarik kertas yang diperoleh juga berbedabeda.(Asngad, 2014).

\subsection{Serat Aren}

Serat aren dapat diproses menjadi selulosa dengan proses delignifikasi nitrat soda 2. Pada proses delignifikasi menggunakan nitrat soda dengan berat bahan 10 gram, volume $\mathrm{HNO}_{3} 400$ ml, konsentrasi $\mathrm{HNO}_{3} 7,5 \%$, waktu 1 jam, suhu proses $103 \pm 20 \mathrm{C}$, kecepatan pengadukan 400 rpm, volume $\mathrm{NaOH} 400 \mathrm{ml}$, diperolah kondisi relatip baik dengan menggunakan konsentrasi $\mathrm{NaOH} 7,5 \%$ dengan waktu 1,5 jam. Pada kondisi tersebut diperoleh hasil : yield produk $33,41 \%$.kadar a selulosa $95,74 \%$ dan dapat dikategorikan sebagai pulp serat panjang (Purnawan, 2014).

\subsection{Ekstrak Daun Kirinyuh}

Ekstrak daun kirinyuh (Eupatorium odoratum) memberikan pengaruh terhadap mortalitas rayap Coptotermes sp. Hasil tersebut menunjukan bahwa tingkat mortalitas meningkat meskipun pada konsentarsi tertinggi mortalitas mengalami penurunan. Adanya kandungan ekstrak daun kiriyuh. Pada kertas menimbulkan anti dan menyebabkan rayap mengurangi jumlah makan yang dikonsumsi sehingga rayap megalami mortalitas. Ekstrak daun kiriyuh (E. odoratum) pada kertas juga bersifat toksik terhadap rayap, sehingga dapat digunakan sebagai pengendali rayap Coptotermes sp. Konsentrasi ekstrak daun kirinyuh pada kertas yang efektif (LC-50) sebagai bahan pengendali rayap pada konsentrasi 2,5\% (Hadi, 2008).

\section{KESIMPULAN}

Hasil analisis yang dilakukan didapat bahwa banyak bahan alternatif yang dapat digunakan untuk pembuatan kertas, bahan alternatif tersebut berasal dari jenis tanaman yang bisa dimanfaatkan untuk membuat kertas. Dengan banyaknya bahan-bahan alternatif dalam pembuatan kertas ini membuat kita menjadi kreatif dan inovatif dalam pemanfaatan tumbuhan yang ada disekitar kita. Penelitian ini menunjukan bahwa tanaman yang banyak digunakan sebagai bahan-bahan alternatif dalam pembuatan kertas adalah tumbuhan dari family poaceae dengan kertas yang dihasilkan adalah kertas seni (art paper), sedangkan yang dapat digunakan untuk kertas tulis adalah menggunakan tandan kosong kelapa sawit. Dalam analisis ini juga ditemukan dalam pembuatan kertas banyak menggunakan proses secara kimia (chemical pulping) dengan $\mathrm{NaOH}$, seperti pada Batang Pisang, Eceng Gondok, kulit kacang, Bulu Ayam, Rumput Gajah dan Serat Aren.

\section{DAFTAR PUSTAKA}

Asngad, A., 2016, Pemanfaatan Kulit Kacang Dan Bulu Ayam Sebagai Bahan Alternatif Pembuatan Kertas Melalui chemical pulping dengan menggunakan $\mathrm{NaOH}$ dan $\mathrm{CaO}$, Universitas Muhammadiah Surakarta, Surakarta.

Asngad, A., Septian N.I.T., Enggar R.S., Pemanfaatan Rumput Gajah (pennisetum purpureum) untuk.Pembuatan Kertas Melalui chemical pulping menggunakan $\mathrm{NaOH}$ dan $\mathrm{Na}_{2} \mathrm{CO}_{3}$, Universitas Muhammadiah Surakarta, Surakarta. (https://media.neliti.com/media/publications/172534-ID-pemanfaatan-rumput gajahpennisetum-purp.pdf)

Bahri, S, 2015, Pembuatan Pulp dari batang pisang, Jurnal Teknologi Kimia Unimal 4:2 hal. 36-50.

Fatyasari N.I., Helda N, Choir M., 2013, Pemanfaatan serat selulosa Eceng gondok (eichhornia crassipes) sebagai bahan baku Pembuatan kertas: isolasi dan karakterisasi, Universitas Lambung Mangkurat

Hadi, M., 2008, Pembuatan Kertas Anti Rayap Ramah Lingkungan dengan Memanfaatkan Ekstrak Daun Kirinyuh (Eupatorium odoratum), Jurnal Bioma. 
Jurnal Inkofar * Volume 1 No. 2, Desember 2017 * ISSN: 2615-3645 (Print) / 2581-2920 (Online)

Tersedia secara online di: http://www.politeknikmeta.ac.id/meta/ojs/

Lopes, A., 2013, Pemanfaatan Jerami Padi (oryza sativa) Menjadi kertas seni (art paper) dan produk kerajinan, Politeknik Pertanian Negeri Samarinda, Samarinda.

Purnawan, Cyrilla I.P., 2014, Pembuatan Pulp Dari Serat Aren (Arenga Pinnata) dengan Proses Nitrat Soda, Prosiding Seminar Nasional Aplikasi Sains dan Teknologi.

Putri D.P., 2015, Pemanfaatan Kulit Jagung Dan Tongkol Jagung (Zea Mays) Sebagai Bahan Dasar Pembuatan Kertas Seni Dengan Penambahan Natrium Hidroksida (Naoh) Dan Pewarna Alami. Universitas Muhammadiah Surakarta, Surakarta.

Syamsu K., Liesbetini H., Gamma I.P., Han R., 2014, Campuran Pulp Tandan Kosong Kelapa Sawit dan Selulosa Mikrobial Nata de Cassava dalam Pembuatan Kertas, Jurnal Ilmu Pertanian Indonesia.

Vitaloka, A., 2017, Karakteristik kertas berbahan baku ampas tebu dan sampah kertas, Universitas Sumatera Utara, Medan. 